\title{
Analisis Citra Satelit MTSAT dan TRMM menggunakan Software ER MAPPER, SATAID dan PANOPLY saat Kejadian Curah Hujan Ekstrim di Wilayah Manado, 16 Februari 2013
}

\author{
Novvria Sagita* dan Ratih Prasetya \\ Stasiun Meteorologi Sam Ratulangi Manado \\ Jl. AA Maramis Bandara Sam Ratulangi, Manado 59374
}

\begin{abstract}
Intisari
Stasiun meteorologi Sam Ratulangi Manado mencatat jumlah curah hujan pada tanggal 16 Februari 2013 adalah $237,5 \mathrm{~mm}$ yang mengindikasikan curah hujan ekstrim. Pada hari berikutnya tanggal 17 Februari 2013 terjadi banjir di wilayah Manado. Analisis nilai piksel citra satelit MTSAT (Multifunctional Transport Satellites) pada kanal IR (Infrared) menggunakan software ER Mapper menunjukkan adanya kenaikan nilai pixel pada pukul 08.00 UTC yang berarti bahwa suhu puncak awan rendah. Analisis citra satelit IR menggunakan software SATAID (GMSLPW) menunjukan adanya tutupan awan merata di wilayah Manado mulai pukul 11.00 UTC, dan citra satelit visibel menunjukan nilai indeks albedo tertinggi yaitu 0,49 pada pukul 05.00 UTC. Pengamatan akumulasi curah hujan meggunakan software TRMM (Tropical Rainfall Measuring Mission) pada 16 Februari 2013 mencapai 205,2 mm.
\end{abstract}

\begin{abstract}
The amount of rainfall recorded in Sam ratulangi Meteorological station on February 16th 2013 was 237,5 mm which indicats an extreme rainfall. On the next day, February $17^{\text {th }} 2013$, there was flooding in the area of Manado. The pixel value analysis of MTSAT (Multifunctional Transport Satellites) on IR(infra red) channel by using ER Mapper software shows an increase pixel value at 08.00 UTC that indicats low temperature at the top clouds. The analysis of satellite image on IR channel by using SATAID software (GMSLPW) shows that the cloud was covering most of Manado area starting at 11.00 UTC, and analysis of satellite image on Visible channel shows the highest value of albedo index which reach 0.49 at 05.00 UTC. The observation of rainfall accumulation by using TRMM (Tropical Rainfall Measuring Mission) software on February $16^{\text {th }} 2013$ reached $205.2 \mathrm{~mm}$.
\end{abstract}

KATA KUNCI: extreem rainfall, pixel, infrared,visible, TRMM

\section{PENDAHULUAN}

Posisi geografis Indonesia terletak di region lintang rendah (low latitudes) [1]. Sebagian besar wilayah Indonesia (70\%) terdiri atas lautan, jumlah air yang menguap sangatlah besar, formasi awan yang terbentuk juga unik dan berfluktuasi [2]. Salah satu indikasi fluktuasi cuaca adalah cuaca ekstrim.

Cuaca ekstrim adalah keadaan atau fenomena fisik atmosfer pada waktu tertentu dan berskala jangka pendek dan bersifat ekstrim. BMKG mengkategorikan kriteria cuaca ekstrim apabila suhu udara permukaan $\geq 35^{\circ} \mathrm{C}$, kecepatan angin $\geq 25$ knot, curah hujan sehari $\geq 50 \mathrm{~mm}$ [3]. Kejadian cuaca ekstrim dapat diketahui dari pemanfaatan alat alat pemantau cuaca.

Citra satelit banyak digunakan untuk keperluan mendeteksi potensi sebaran awan hujan, citra satelit yang digunakan

*E-MAIL: novvria.sagita@bmkg.go.id umumnya channel IR dan visible. Kedua channel ini dimanfaatkan untuk mendapatkan interpretasi yang mendekati kenyataan. Citra satelity IR adalah hasil gambar yang diperoleh berdasarkan pantulan suhu, sedangkan citra satelit visible diperoleh berdasarkan tingkat refleksifitas permukaan [3].

Satelit MTSAT merupakan satelit yang dimiliki jepang dan memiliki 4 kanal yaitu IR1, IR2, IR4, VIS. Empat kanal citra satelit MTSAT masing-masing memiliki karakteristik kegunaan masing-masing [3].

Stasiun meteorologi Sam Ratulangi Manado mencatat pada 16 Februari 2013 curah hujan mencapai 237,5 mm/hari . Hal ini menunjukkan Manado mengalami curah hujan ekstrim. Dengan kejadian tersebut diperlukan analisis tutupan awan dengan citra satelit di Manado pada 16 Februari 2013 dengan menganalisis suhu puncak awan dari nilai piksel dan mengetahui pola tutupan awan dan besaran akumulasi curah hujan dengan pengamatan satelit TRMM.

Tujuan penulisan ini untuk mengetahui nilai piksel, mengetahui pola tutupan awan dengan citra IR dan visibel, serta besaran nilai akumulasi curah hujan satelit TRMM di Manado 
pada tanggal 16 Februari 2013.

Satelit MTSAT/ GMS (Geostasionary Meteorological Satellite) berorbit pada posisi tetap yaitu $140^{\circ}$ BT tepat terletak di kota Biak dengan ketinggian $\pm 36000 \mathrm{~km}$ dari permukaan bumi dan memantau tempat yang sama $1 / 3$ bumi dari luas bumi. Data satelit ini diterima rutin setiap satu jam oleh Badan Meteorologi Klimatologi dan Geofisika Jakarta. Pengamatan yang dilakukan satelit MTSAT meliputi permukaan bumi, liputan awan, angin, badai, ENSO (El Nino and Southern Oscilation), posisi dan gerak ITCZ (Inter Tropical Convergence Zone), menduga curah hujan.

Satelit MTSAT memiliki dua sensor yaitu :

1. Infrared terdiri dari:

- IR-1 yang memiliki panjang gelombang 10,3 $11,3 \mu \mathrm{m}$ yang memiliki resolusi $5 \mathrm{~km}$ (10 bit) yang diaplikasikan untuk awan, pergerakan awan, pergerakan angin, dan badai.

- IR-2 memiliki panjang gelombang 11,5 - 12,5 $\mu \mathrm{m}$ dengan resolusi $5 \mathrm{~km}$ (10 bit) yang diaplikasikan suhu permukaan laut, dan memantau gunung berapi.

- IR-3 atau disebut water vapour memiliki panjang gelombang 6,5 - $7 \mu \mathrm{m}$ dengan resolusi $5 \mathrm{~km}$ (10 bit) yang diaplikasikan untuk monitoring pergerakan uap air di lapisan tengah atmosfer.

- IR-4 disebut near infrared (NIR) memiliki panjang gelombang 3,5 - 4,0 $\mu \mathrm{m}$ dengan resolusi $5 \mathrm{~km}$ (10 bit) yang diaplikasikan untuk sumber panas dan awan pada malam hari.

2. Visibel digunakan untuk mendeteksi awan dengan melihat besarnya albedo obyek, sehingga sensor ini hanya dapat bekerja pada siang hari karena data bergantung albedonya dari pantulan sinar matahari [3].

\section{Albedo}

Albedo berasal dari bahasa latin yaitu albus yang berarti putih yaitu perbandingan antara radiasi gelombang pendek yang dipantulkan dengan sinar datang dari semua spektrum panjang gelombang. Formula albedo dapat ditulis sebagai

$$
\alpha=\frac{R_{s} \uparrow}{R_{s} \downarrow}
$$

dengan, $\alpha$ adalah albedo, $\mathrm{r} \uparrow$ adalah radiasi gelombang pendek yang dipantulkan, $r \downarrow$ adalah radiasi gelombang pendek yang datang.

Albedo menunjukkan sifat kehitaman badan objek. Albedo mempunyai kisaran nilai $0-1$. Bila suatu objek mempunyai nilai albedo $=0$ maka objek tersebut mengabsorbsi seluruh radiasi gelombang pendek yang datang dan albedo $=1$ maka objek tersebut memantulkan seluruh radiasi gelombang pendek yang datang. Namun, tidak ada satu pun benda di alam semesta yang memiliki albedo bernilai 0 atau 1 , yang

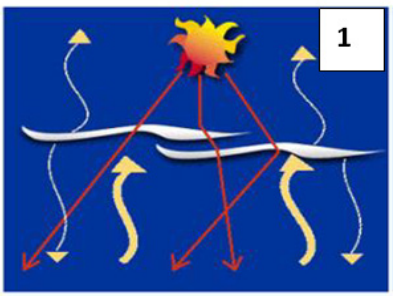

(a)

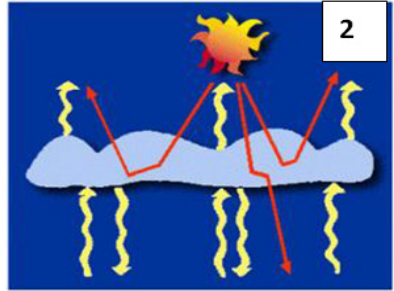

(b)
Gambar 1: Perilaku gelombang pendek jika mengenai awan tinggi dan awan rendah [5]

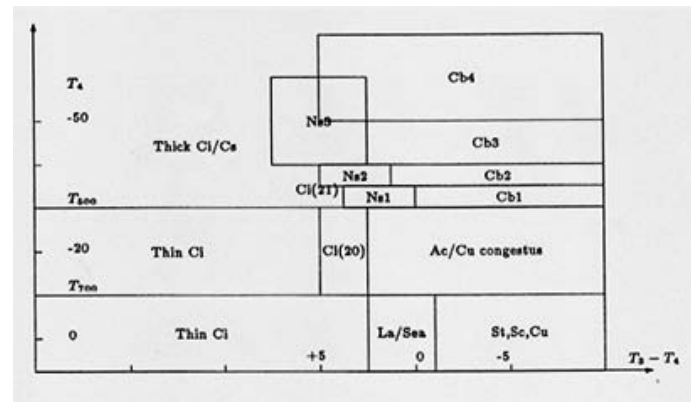

Gambar 2: Klasifikasi jenis awan berdasarkan suhu puncak awan [6].

ada hanya mendekati 0 dan 1 . Semakin mendekati nilai nol maka kenampakan suatu objek semakin gelap dan semakin mendekati nilai satu maka kenampakan suatu objek semakin cerah [4].

Gambar 1 menunjukan sifat gelombang pendek jika mengenai awan-awan tinggi cenderung meneruskannya (1) dan jika mengenai awan-awan rendah cenderung memantulkanya (2).

Klasifikasi jenis awan berdasarkan pengamatan suhu puncak awan kanal IR, ditunjukkan Gambar 2. Berdasar Gambar 2 diketahui bahwa salah satu indikasi adanya awan $\mathrm{Cu}$ mulonimbus yang biasanya menghasilkan curah hujan tinggi yang memicu curah hujan ekstrim dan banjir.

Satelit TRMM dikeluarkan NASA untuk mengukur curah hujan di wilayah tropis. Pengamat curah hujan meliputi wilayah lautan yang mana tidak ada pengamatan secara manual dilakukan. TRMM akan memberikan informasi keberadaan awan dan hujan. TRMM tidak hanya memberikan data curah hujan tapi yang lebih penting juga memberikan informasi panas yang terjadi di atmosfer sebagai bagian proses hujan.

Satelit TRMM memiliki 4 sensor PR (Precipitation Radar), TMI (TRMM Microwave Imager), VIRS (Visibel and Infrared Scanner), CERES (Cloud and Earth Radiant Energy), tetapi data yang digunakan untuk mengambil data pengamatan hujan adalah PR dan TMI [7]. 


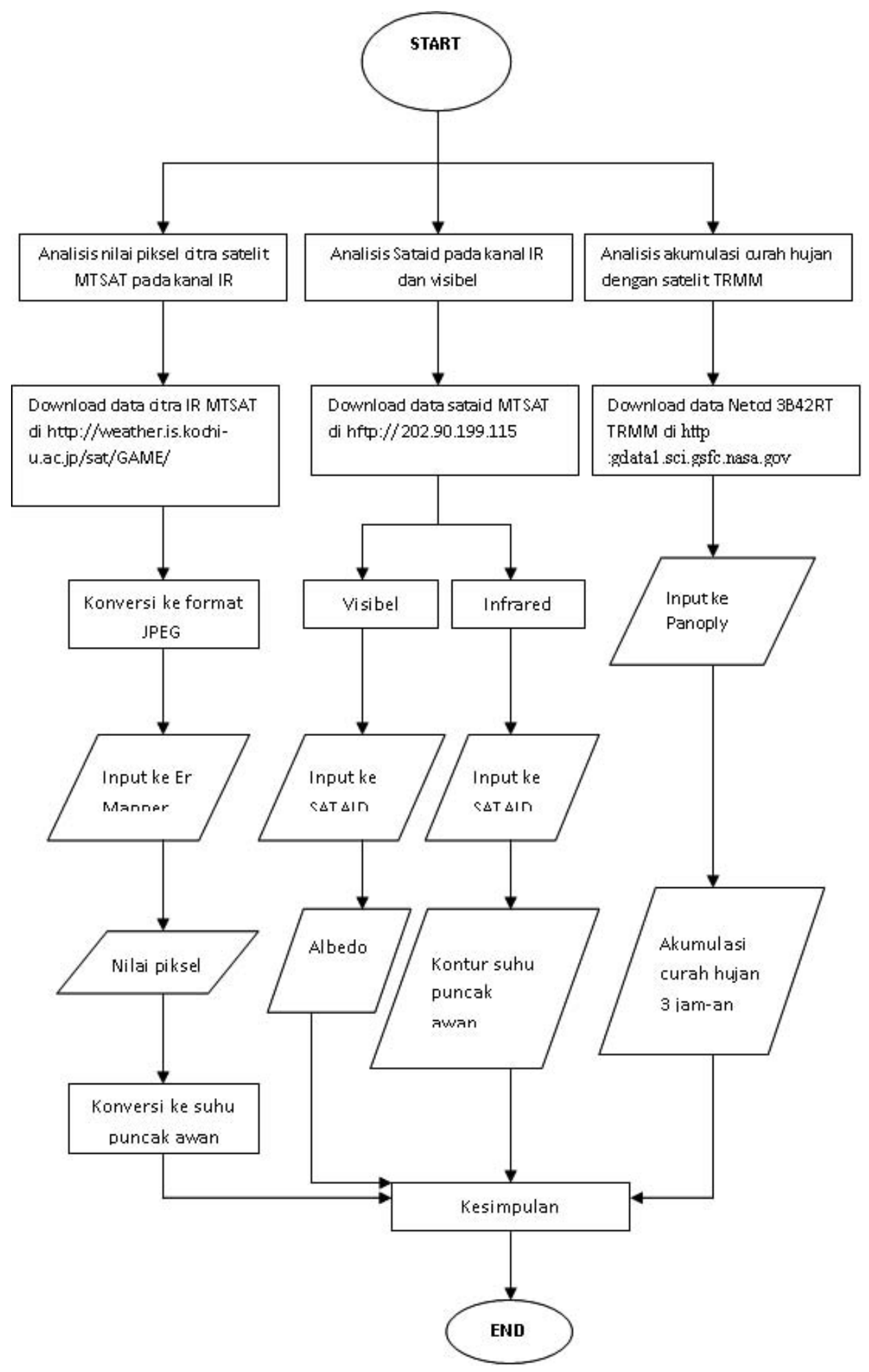

Gambar 3: Alur kerja penelitian.

\section{DATA DAN METODOLOGI}

Lokasi yang akan diamati adalah Manado $\left(1,5^{\circ} \mathrm{LU}\right.$ dan $124,9^{\circ} \mathrm{BT}$ ) pada tanggal 16 Februari 2013. Alat yang digunakan dalam penelitian ini adalah perangkat lunak Er Mapper
6.0, perangkat lunak GMSLPW, perangkat lunak Panoply 3.1.7. Data yang digunakan dalam penelitian ini adalah data Citra Satelit IR1 MTSAT resolusi 1800 x 1800 piksel untuk area $70^{\circ} \mathrm{LU}-20^{\circ} \mathrm{LS}$ dan $70^{\circ} \mathrm{BT}-160^{\circ} \mathrm{BT}$ [8], citra data SATAID Satelit MTSAT IR1 dan Visibel [9], data satelit 
TRMM 3B42RT resolusi 0,25 piksel durasi 3 jam-an [10].

Metodologi penelitian dilakukan dengan beberapa tahap, sebagai berikut:

1. Mendownload data Citra Satelit IR1 MTSAT resolusi 1800 x 1800 piksel untuk area $70^{\circ}$ LU- $20^{\circ} \mathrm{LS}$ dan $70^{\circ} \mathrm{BT}-160^{\circ} \mathrm{BT}$.

2. Mengkonversi data yang didownload kedalam format JPEG.

3. Membuka data yang telah dikonversi dalam JPEG di perangkat lunak ER Mapper 6.0.

4. Mengkonversi letak kordinat kota Manado ke dalam kordinat Piksel denga rumus

5. Bujur $=(\mathrm{x}-70) \cdot 20$ dan lintang $=1800-(\mathrm{y}+20) \cdot 20$.

6. Membaca nilai piksel kota Manado pada tanggal 16 Februari 2013 tiap jam.

7. Mengkonversi nilai piksel ke dalam suhu puncak awan dengan tabel dari Kochi.

8. Membandingkan suhu puncak awan dari piksel citra satelit dengan suhu puncak awan dari analisis SATAID di perangkat lunak GMSLPW.

9. Menganalisis citra Satelit IR dan Visibel dengan perangkat lunak SATAID.

10. Mendowload data 3B42RT TRMM

11. Memplotting data di perangkat lunak panoply 3.1.7 dan atur kordinat data akumulusai curah hujan yang ingin ditampilkan.

12. Melihat nilai akumulasi curah hujan di Manado pada tanggal 16 februari 2013.

13. Menghitung nilai pengamatan akumulasi curah hujan selama satu hari pada tanggal 16 Februari 2013.

Alur kerja penelitian ditunjukkan secara skematis oleh Gambar 3 .

\section{HASIL DAN PEMBAHASAN}

\section{Analisis konversi nilai piksel ke suhu puncak awan di Manado pada tanggal 16 Februari 2013.}

Pengolahan data citra satelit IR 1 MTSAT resolusi $1800 \mathrm{x}$ 1800 piksel, diperoleh grafik nilai piksel tiap jam pada tanggal 16 Februari 2013 di Manado, seperti ditunjukkan Gambar 4, sedangkan grafik suhu puncak awan dari konversi piksel dan SATAID ditunjukkan Gambar 5.

Kedua grafik pada Gambar 4 dan 5 menunjukkan hubungan terbalik antara nilai piksel citra satelit dengan suhu puncak

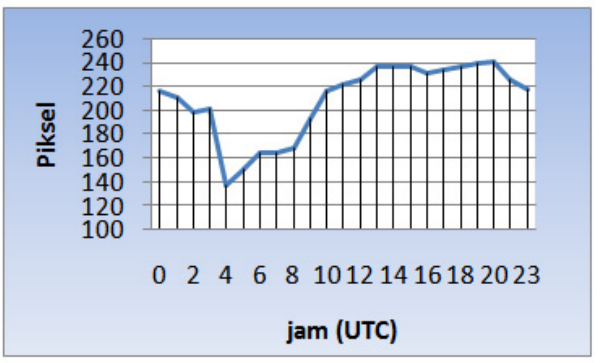

Gambar 4: Grafik nilai piksel citra satelit MTSAT IR 16 Februari 2013.

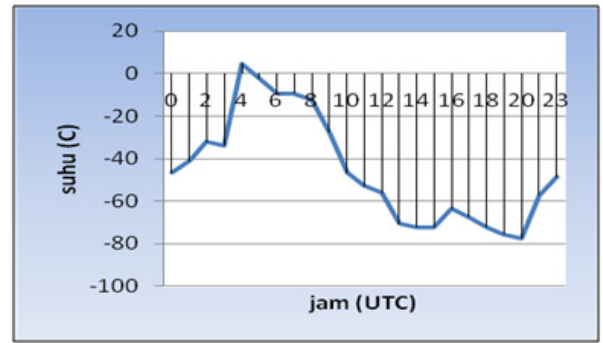

Gambar 5: Grafik suhu puncak awan dari konversi piksel dan SATAID.

awan. Dari dua grafik tersebut terlihat bahwa semakin besar nilai piksel maka akan semakin rendah suhu puncak awan. Kenaikan nilai piksel terjadi mulai pukul 08.00 UTC. Terlihat hampir sepanjang hari pada tanggal 16 Februari 2013 suhu puncak awan dibawah $-40^{\circ} \mathrm{C}$ yang mengindikasikan adanya awan Cumulonimbus pada hari itu.

\section{Analisis curah hujan Stasiun Meteorologi Sam Ratulangi Manado pada tanggal 16 Februari 2013.}

Data curah hujan penangkar Hellman stasiun meteorologi Sam Ratulangi Manado (Gambar 6) menunjukkan terdapat 3 puncak curah hujan pada tanggal 16 Februari 2013 yaitu kisaran pukul 08.00 UTC sebesar 21,6 mm, pukul 13.00 UTC sebesar 32,9 mm, dan pukul 21.00 UTC sebesar $24,2 \mathrm{~mm}$. Data suhu puncak awan dari konversi piksel dan SATAID memiliki keserasian dengan data curah hujan tersebut karena untuk data sataid pada pukul 06.00 - 09.00 UTC memiliki

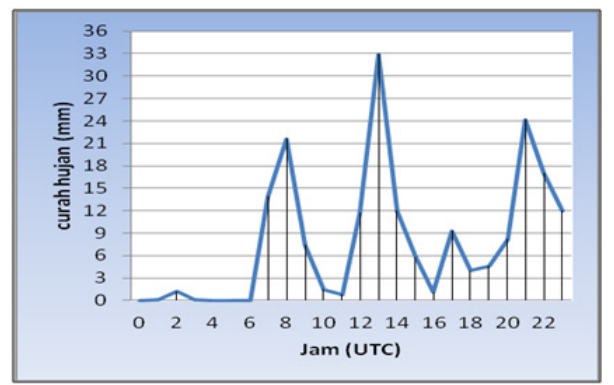

Gambar 6: Grafik curah hujan Hellman. 


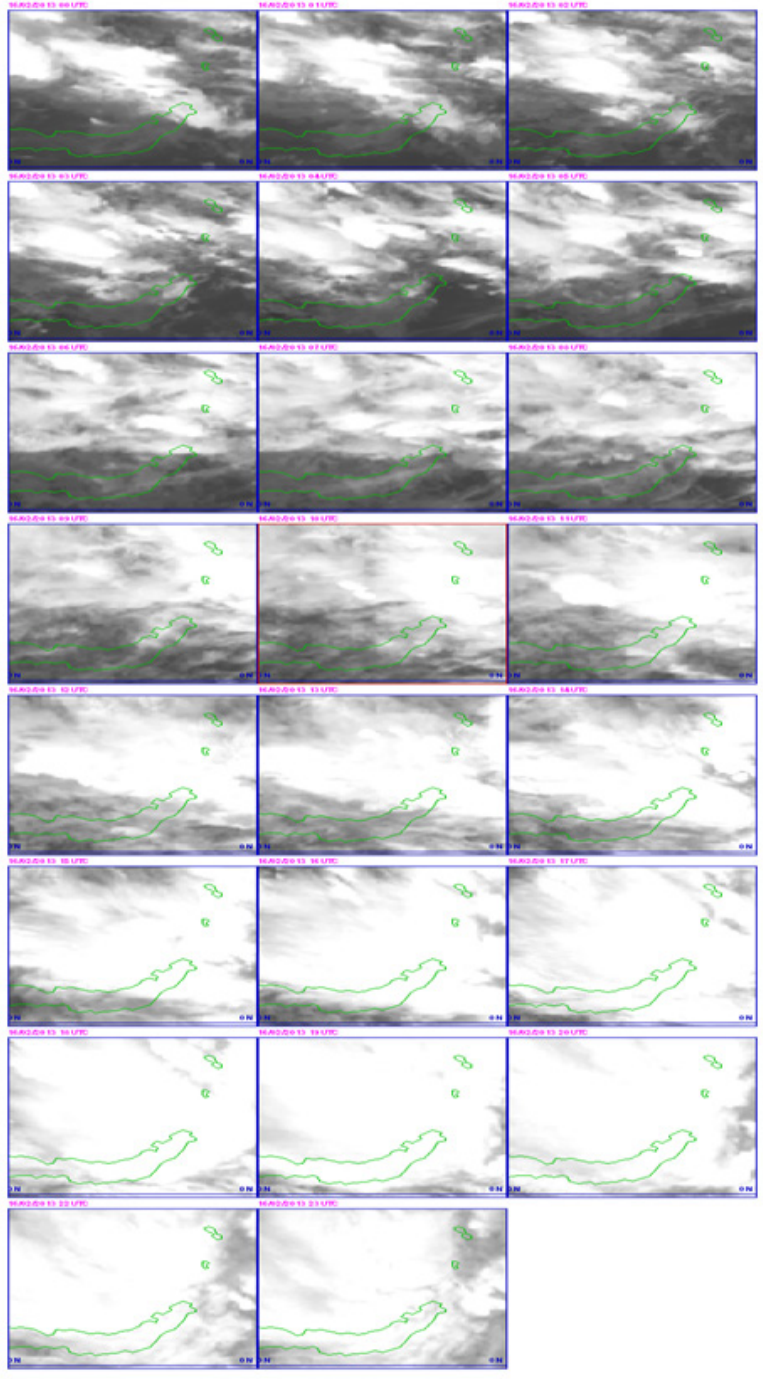

Gambar 7: Citra satelit IR MTSAT.

suhu puncak awan di bawah $-40^{\circ} \mathrm{C}$, pukul 12.00 - 15.00 UTC memiliki suhu puncak awan di bawah $-50^{\circ} \mathrm{C}$ dan pada pukul 18.00 - 21.00 UTC memiliki suhu puncak awan di bawah $-60^{\circ} \mathrm{C}$ yang mengindikasikan adanya awan Cumulonimbus pada jam-jam tersebut.

\section{Analisis citra satelit IR MTSAT}

Citra satelit IR 1 (Gambar 7) menunjukkan pada saat kejadian curah hujan ekstrim yaitu pada pukul 08.00 UTC, citra satelit IR tidak terlihat terlalu pekat dan merata warna putihnya (untuk interprestasi warna, pembaca dapat melihat artikel ini versi web) sehingga ini yang menyebabkan nilai konversi piksel ke suhu puncak awan memiliki nilai suhu puncak awan yang tinggi. Berbeda dengan citra satelit pada pukul 13.00 dan 21.00 UTC terlihat citra satelit yang putih pekat dan merata di atas wilayah Manado sehingga nilai piksel tinggi yang mengindikasikan suhu puncak awan yang rendah. Citra satelit IR 1 digunakan untuk melihat suhu puncak awan pada perangkat lunak GMSLPW dan dapat diperoleh kontur

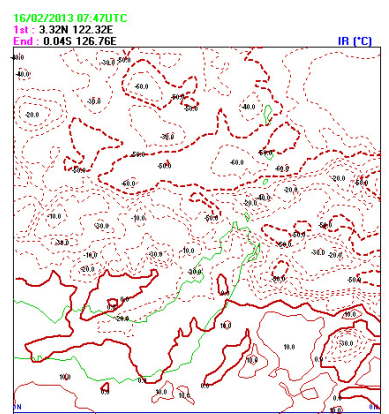

(a)

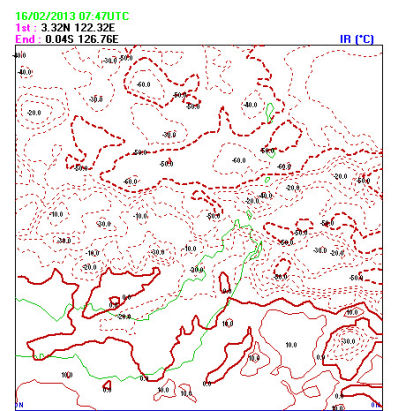

(b)

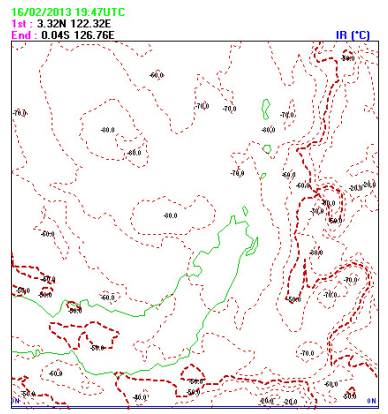

(c)

Gambar 8: Kontur suhu puncak awan pada pukul 08.00, 13.00 dan $20.00 \mathrm{UTC}$

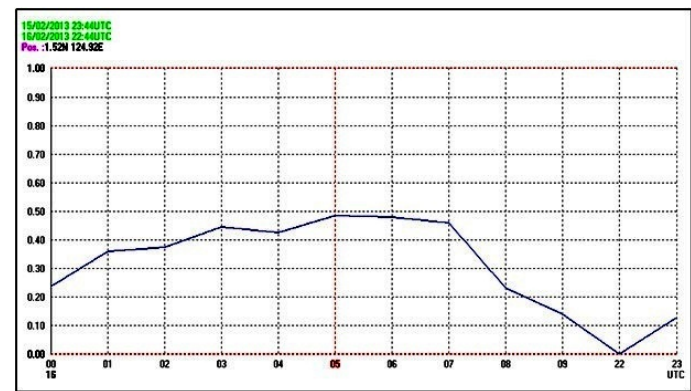

Gambar 9: Grafik nilai albedo awan.

suhu puncak awan seperti pada Gambar 8. Kontur suhu puncak awan menunjukkan pada pukul 08.00 UTC suhu puncak awan sebesar $-30^{\circ} \mathrm{C}$, pada $13.00 \mathrm{UTC}$ sebesar $-60^{\circ} \mathrm{C}$ dan pada 21.00 UTC sebesar $-70^{\circ} \mathrm{C}$, yang mengindikasikan awan $\mathrm{Cu}-$ mulonimbus makin kuat.

\section{Citra visibel satelit MTSAT}

Grafik pada Gambar 9 adalah grafik nilai albedo dari citra satelit visible MTSAT, yang menunjukkan nilai indeks albedo maksimum terjadi pada pukul 05.00 UTC yaitu sebesar 0,49, hal ini menunjukkan banyaknya daerah tutupan awan rendah pada saat itu sehingga dapat diketahui adanya kemungkinan curah hujan yang tinggi. Terlihat pada citra satelit visible adanya daerah tutupan awan di atas wilayah Manado. 


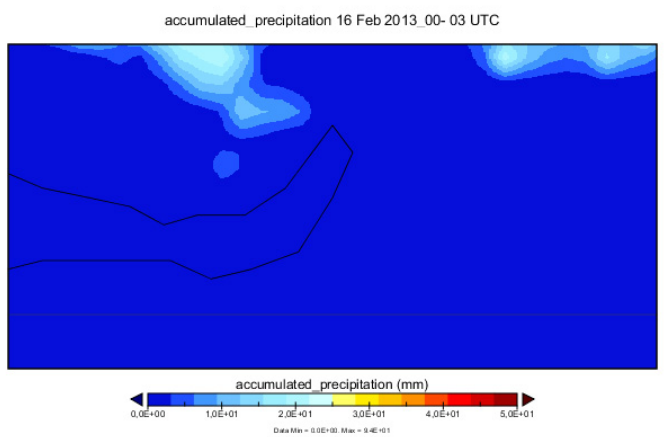

(a)
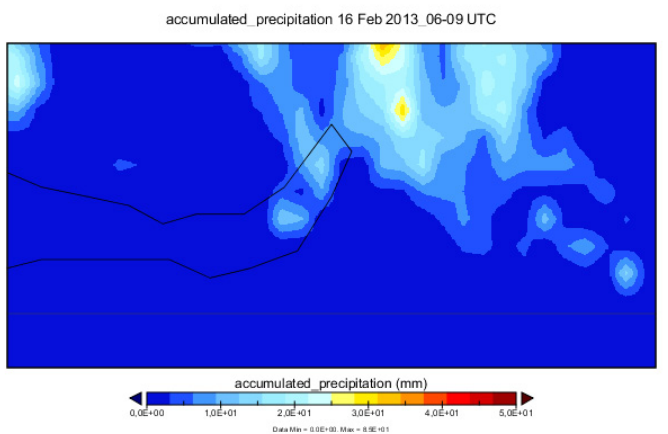

(c)

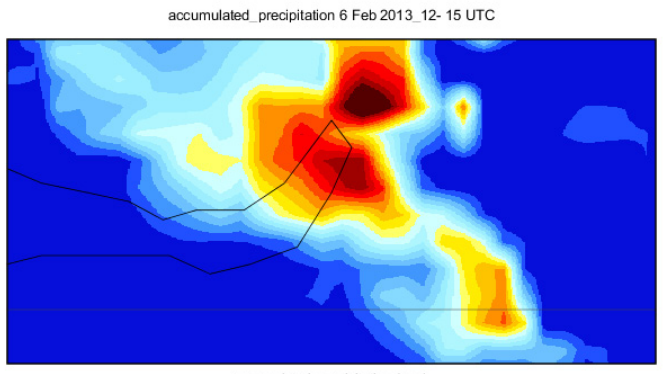

ace accumulated precipitation (mm)

(e)

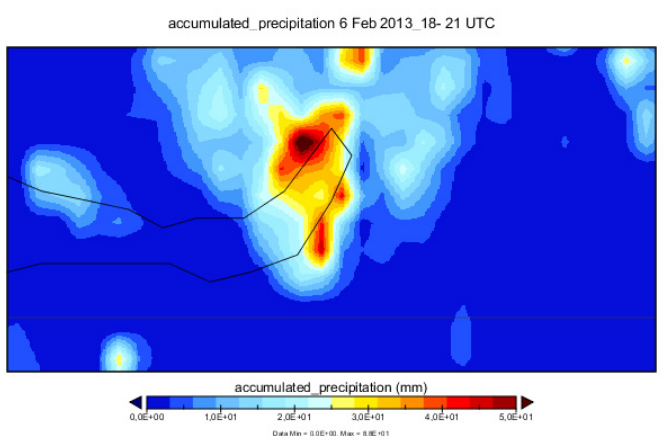

(g)

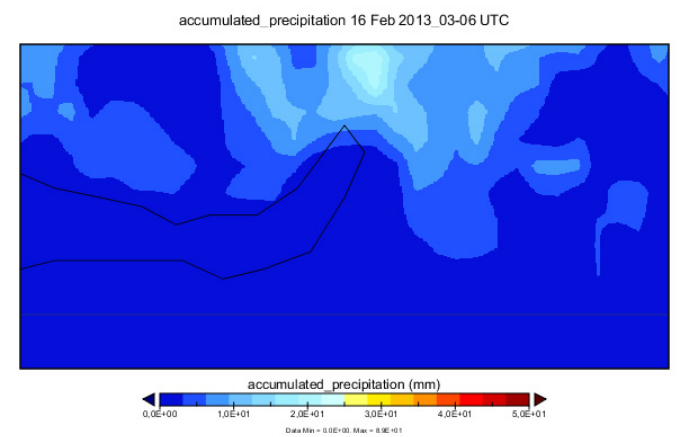

(b)

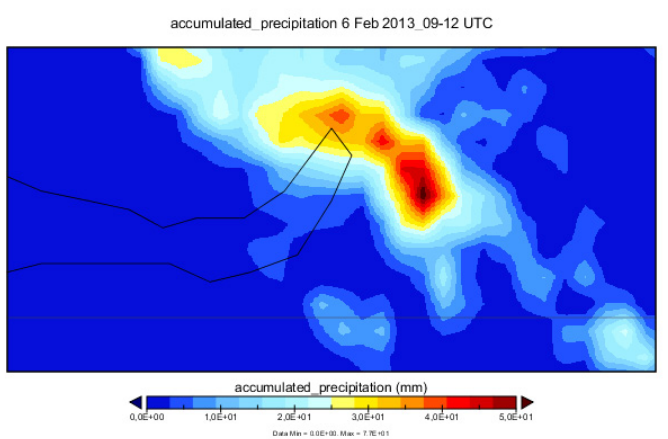

(d)

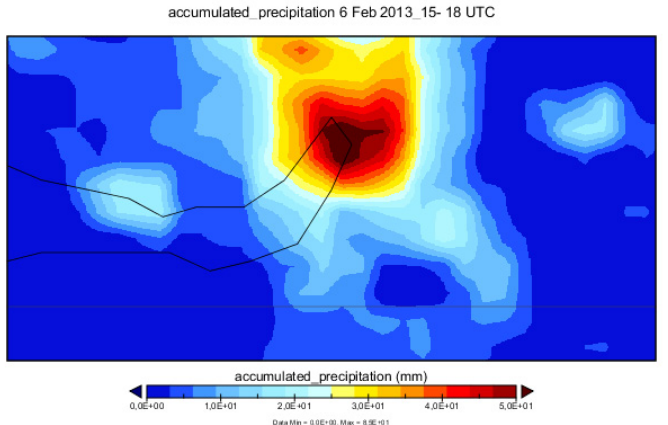

(f)

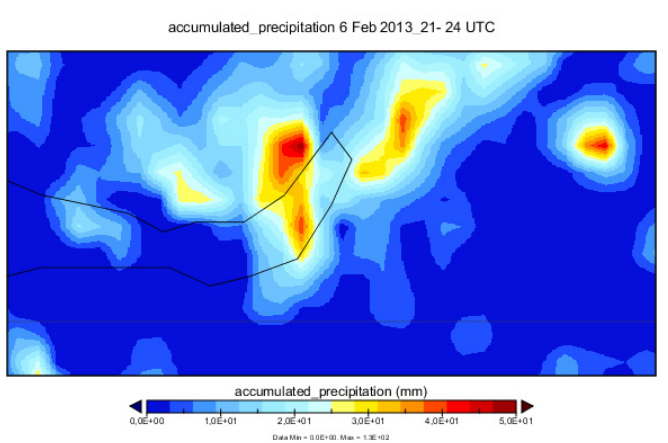

(h)

Gambar 10: Citra satelit tiap 3 jam akumulasi curah hujan pada tanggal 16 februari 2013 menggunakan TRMM. 


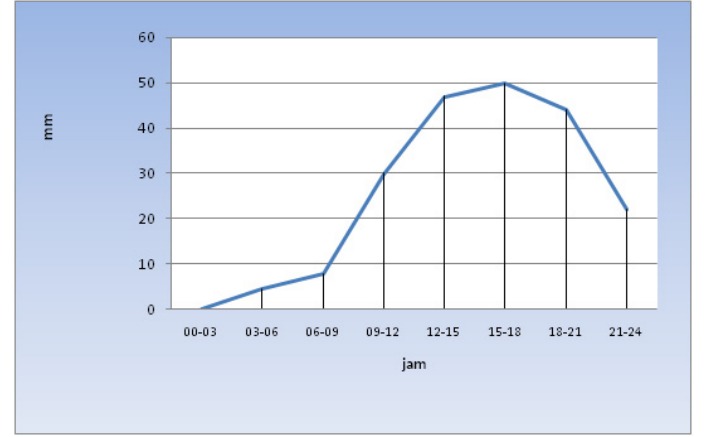

Gambar 11: Grafik akumulasi curah hujan per 3 jam pada citra satelit TRMM.

\section{Analisis akumulasi curah hujan dengan citra satelit TRMM}

Citra satelit pada Gambar 10 menunjukan terjadi hujan hampir sepanjang hari di wilayah Sulawesi Utara bagian utara pada tanggal 16 Februari 2013 dan berdasarkan citra satelit tersebut dapat diketahui nilai akumulasi curah hujan pada tanggal 16 Februari 2013 mencapai 205,2 mm.

Grafik pada Gambar 11 menunjukkan puncak curah hujan terjadi pada pukul 15.00 - 18.00 UTC dengan jumlah hujan sebanyak $50 \mathrm{~mm}$ dan dapat diketahui bahwa curah hujan terus meningkat sejak pagi hari, puncak hujan terjadi antara pukul 15.00 - 18.00 dan kemudian menurun.

\section{SIMPULAN}

Berdasarkan uraian tersebut diatas maka dapat disimpulkan bahwa:

1. Nilai piksel yang teramati pada tanggal 16 februari 2013 hampir sepanjang hari mencapai nilai di atas 200 yang menunjukkan semakin tinggi nilai piksel maka semakin rendah suhu puncak awan (dibawah -30).

2. Pada citra satelit MTSAT pada kanal IR menunjukan citra putih pekat pada saat terjadinya puncak curah hujan yaitu antara pukul 13.00 dan 21.00 UTC pada saat merupakan puncak curah hujan pada 16 Februari 2013.

3. Pada citra satelit MTSAT pada kanal visible menunjukan puncak albedo pada pukul 05.00 UTC mencapai 0,49 .

4. Analisis peta data TRMM 3B42RT menunjukan akumulasi curah hujan pada tanggal 16 Februari 2013 mencapai $205,2 \mathrm{~mm} /$ hari.
[1] S. Nieuwolt, Tropical Climatology (John Willey \& Son Inc. New York, Toronto, 1977).

[2] HK. B. Tjasyono, Meteorology of the Indonesia Maritime Continent, Volume I, Characteristics and Circulation of the Atmosphere, Indonesia Meteorological and Geophysical Agency (BMG), 2007.

[3] Tim BMKG, Diklat Teknis Meteorologi Publik (Pusat Pendidikan dan Pelatihan Meteorologi, Klimatologi dan Geofisika, Jakarta, 2009).

[4] D. Rumondang, Penurunan nilai albedo dan suhu permukaan dari data Terra MODIS L1B untuk klasifikasi awan, Skripsi, Fakultas Geofisika dan Meteorologi, Institut Pertanian Bogor, 2011.

[5] National Aeronautics and Space Administration, Cloud and Particles, 2010 (http://earthobservatory.nas a.gov/Features/Clouds/), diakses 20 Maret 2013.

[6] Shimizu, Cloud type indentification by meteorological satellites, Workshop on Weather Saatellite and Radar Data Interpretation and Analysis, Japan Meteorological Agency, 2007.

[7] R. Findy, dan M.D. Syaifulloh, Kajian meteorologis bencana banjir bandang di Wasior, Papua Barat, Jurnal Meteorologi dan Geofisika, 12(1), 33-41 (2011).

[8] Satellite images, 2013,(www.weather.is.kochiu.ac.jp/sat/GAME/ 2006/Apr/CAL/), diakses 15 Maret 2013

[9] SATAID data, 2013, (ftp://202.90.199.115), diakses 15 Maret 2013.

[10] 3B42RT data, 2013, (http:gdata1.sci.gsfc.nasa.gov), diakses 15 Maret 2013. 